


\title{
PENGARUH PERAN KELUARGA, AKTIVITAS FISIK, INTERAKSI SOSIAL DAN STRES TERHADAP KUALITAS HIDUP LANSIA
}

\author{
Riza Savita $^{1}$, Rindu ${ }^{2}$ \\ ${ }^{1,2}$ Sekolah Tinggi Ilmu Kesehatan Indonesia Maju \\ 1'rizasavita55@gmail.com, ${ }^{2}$ rindualghie@gmail.com
}

\begin{abstract}
ABSTRAK
Kualitas hidup merupakan suatu konsep yang luas terdiri dari kesehatan fisik, psikologis, hubungan sosial dan hubungan dengan lingkungan. Masa lansia akan mengalami suatu perubahan dalam segi fisik, kognitif maupun dalam kehidupan psikososialnya sehingga dapat mempengaruhi kualitas hidup lansia tersebut. Tujuan penelitian ini adalah untuk mengetahui pengaruh langsung dan tidak langsung serta besaran antara peran keluarga, aktivitas fisik, interaksi sosial, dan stres terhadap kualitas hidup lansia di Puskesmas Petaling Mendobarat Bangka Belitung tahun 2017. Metode penelitian ini adalah pendekatan kuantitatif dengan desain cross-sectional. Jumlah sampel 60 lansia. Metode analisis dengan Structural Equation Model (SEM) mengunakan SmartPLS 2.0. Hasil pengujian hipotesis SEM dengan metode SmartPLS menghasilkan temuan penelitian yaitu peran keluarga $(2,14 \%)$, aktivitas fisik $(13,01 \%)$, interaksi sosial $(57,41 \%)$ dan stres $(13,34 \%)$. Pengaruh langsung kualitas hidup lansia di Puskesmas Petaling Mendobarat Bangka Belitung sebesar $85,90 \%$ dan pengaruh tidak langsung sebesar $6,27 \%$. Total pengaruh langsung dan tidak langsung kualitas hidup lansia sebesar 92,17\%. Semakin tinggi interaksi sosial lansia maka semakin baik kualitas hidup lansia dan sebaliknya semakin rendah interaksi sosial lansia maka semakin buruk kualitas hidup lansia. Saran penelitian adalah Puskesmas sebaiknya meningkatkan program posyandu lansia dan lebih mengoptimalkan senam lansia yang sudah ada sehingga para lansia mampu lebih berinteraksi kepada sesama lansia, petugas kesehatan dan kader.
\end{abstract}

Kata Kunci : Keluarga, Aktivitas Fisik, Interaksi Sosial, Stres, Kualitas Hidup

\begin{abstract}
The quality of life is a concept broad consisting physical of health, psychological, social relationships and relations with an environment. The elderly will experience a change in terms of physical, cognitive life of psychosocial that can affect elderly's quality of life. Purpose of this research is to know the influence direct and indirect brtween roll of family, physical of activity, social interaction, and stress on quality of life for elderly at Petaling Mendobarat Public Health Center in Bangka Belitung 2017. This research method is quantitative approach to the crosssectional design. Total sample of 60 elderly. The method of analysis by Structural Equation Model (SEM) using SmartPLS 2.0.Results hypothesis SEM with SmartPLS produce research findings that is the role of the family $(2,14 \%)$, physical activity $(13,01 \%)$, social interaction $(57,41 \%)$ and stress (13,34\%). Directly effect quality of life for elderly 85,90\% and indirect effect is 6,27\%. Total influence direct and indirect quality of life is $92,17 \%$. The higher social interaction elderly can improve the quality of life. Lower social interaction elderly can be worse quality of life for elderly. Suggestions of this study public health center should be improving one care center for elderly and more optimizing the elderly gymnastic than before. So that, the elderly are able to interact each others, health workers and volunteers.
\end{abstract}

Keywords: Family, Physical Activity,Social Interaction, Stress, Quality of Life. 


\section{Pendahuluan}

Menua atau menjadi tua merupakan suatu keadaan yang terjadi di dalam kehidupan manusia. Proses menua merupakan proses sepanjang hidup, tidak hanya dimulai dari suatu waktu tertentu, tetapi dimulai sejak permulaan kehidupan. Menjadi tua merupakan proses alamiah. Menjadi tua merupakan proses yang tidak dapat dihindari. Masa tua dapat dikatakan masa emas, karena tidak semua orang dapat melaluinya. Proses menua merupakan proses yang terus menerus secara alami. Menua pada manusia merupakan fenomena yang tidak dapat dihindarkan. Semakin baik pelayanan kesehatan satu bangsa, makin tinggi pula harapan hidup masyarakat dan pada gilirannya makin tinggi pula yang berusia lanjut. ${ }^{1}$ Meningkatnya jumlah lansia menimbulkan masalah terutama dari segi kesehatan dan kesejahteraan lansia. Masalah tersebut jika tidak ditangani akan berkembang menjadi masalah yang kompleks dari segi fisik, mental dan sosial yang berkaitan dengan kesehatan dan kesejahteraan mereka. ${ }^{2}$

Kemajuan ilmu pengetahuan dan tekhnologi serta perbaikan sosial ekonomi berdampak pada peningkatan derajat kesehatan masyarakat dan usia harapan hidup, sehingga jumlah populasi lansia juga meningkat. Sampai sekarang ini, penduduk di 11 negara anggota World Health Organization (WHO) kawasan Asia Tenggara yang berusia di atas 60 tahun berjumlah 142 juta orang dan diperkirakan akan terus meningkat hingga 3 kali lipat di tahun 2050. Jumlah lansia di Indonesia pada tahun 2011 sekitar 24 juta jiwa atau hampir 10\% jumlah penduduk yang setiap tahunnya jumlah lansia bertambah rata-rata 450.000 orang. ${ }^{3}$

Bertambahnya jumlah lansia, terdapat banyak permasalahan yang dialami lansia di antaranya tidak berpendidikan, tidak memperoleh akses kesehatan, tidak memiliki jaminan hari tua, tidak memiliki dukungan sosial dari keluarga atau teman untuk merawat mereka. ${ }^{4}$

Konsep kualitas hidup berkaitan dengan kesehatan yaitu memantau intervensi medis tertentu, sering menggunakan istilah "kualitas hidup terkait kesehatan" (HRQOL). Persepektif kesehatan (penyakit), kualitas hidup mengacu pada sosial, ekonomi dan fisik kesejahteraan individu.Kualitas hidup merupakan suatu konsep yang dipadukan dengan berbagai cara seseorang untuk mendapatkan kesehatan fisik, keadaan psikologis, tingkat independen, hubungan sosial, dan hubungan dengan lingkungan sekitarnya. ${ }^{5}$

Keluarga menjadi salah satu pilihan lansia unuk tinggal karena merupakan tempat yang sesuia unruk lansia.Kurangnya partisipasi lansia ini disebabkan karena banyak keluarga yang sibuk dengan urusannya masingmasing. Partisipasi sosial yang meliputi pemeliharaan serta pembinaan dalam hubungan sosial secara aktif dapat mencegah penurunan-penurunan fungsi seperti fungsi kognitif pada lansia yang tentunya berpengaruh kepada kualitas hidup lansia. ${ }^{6}$

Aktivitas fisik yang dilakukan secara teratur terbukti dapat meningkatkan kualitas hidup secara fisik dan mental seseorang. Peningkatan kualitas hidup secara fisik antara lain peningkatan metabolisme glukosa, penguatan tulang dan otot, serta mengurangi kadar kolesterol dalam darah. Peningkatan kualitas hidup secara mental yang diperoleh melalui aktivitas fisik ialah mengurangi stres, meningkatkan rasa antusias dan rasa percaya diri, serta mengurangi kecemasan dan depresi seseorang terkait dengan penyakit yang dialaminya.

Perubahan hidup yang dalami lansia menimbulkan berbagai 
permasalahan, diantaranya berupa ketergantungan terhadap orang lain, gangguan kesehatan, dan kemiskinan. Menurunnya kemampuan merespon stress, kehilangan yang berulang dan perubahan fisik menempatkan lansia pada risiko terkena penyakit dan gangguan fungsional. ${ }^{8}$

Secara keseluruhan tampak bahwa dukungan sosial yang positif berkualitas tinggi dapat meningkatkan ketahanan terhadap stress. Hubungan stress dengan kualitas hidup bahwa stress dapat mengurangi kesejahteraan psikologis jangka pendek dan menimbulkan gejalagejala fisik. Stress dapat memperburuk kesehatan fisik dan psikoligis sehingga dapat menurunkan kualitas hidup. Dukungan sosisal sangat diperlukan pada indvidu yang mengalami stress sebagi sumber untuk melindungi individu dari stress yang berat dan memungkinkan individu untuk mengatasinya dengan baik. ${ }^{9}$

Interaksi sosial merupakan hubungan timbal balik atau hubungan yang saling mempengaruhi antar manusia yang berlangsung sepanjang hidupnya dalam masyarakat.Interaksi sosial dapat berdampak positif terhadap kualitas hidup karena dengan adanya interaksi sosial maka lansia tidak merasakan kesepian, oleh sebab itu interaksi sosial harus tetap di pertahankan dan dikembangkan pada kelompok lansia. Kemampuan lansia untuk terus menjalin interaksi sosial merupakan kunci untuk mempertahankan status sosialnya berdasarkan kemampuannya bersosialisasi. $^{10}$

Berdasarkan data dinas kabupaten bangka jumlah lansia pada tahun 2015 mencapai 525 jiwa. Kabupaten Bangka mempunyai 12 puskesmas yang salah satunya adalah Puskesmas Petaling Mendobarat. Jumlah lansia pada Puseksmas ini merupakan salah satu yang tertinggi.
Tujuan penelitian ini adalah untuk mengetahui pengaruh langsung atau tidak langsung pengaruh peran keluarga, aktivitas fisik, interaksi sosial dan stres terhadap kualitas hidup lansia di Puskesmas Petaling Mendobarat Bangka Belitung.

\section{Metode}

Penelitian ini adalah penelitian kuantitatif dengan desain cross sectional yang gunanya untuk menganalisis hubungan kausal antara variabelvariabel melalui pengujian hipotesis yaitu untuk menganalisis pengaruh langsung dan tidak langsung serta besarannya antara peran keluarga, aktivitas fisik, interaksi sosial dan stres terhadap kualitas hidup lansia di puskesmas petaling mendobarat bangka belitung tahun 2017.

Populasi dalam penelitian ini adalah seluruh lansia yang berjumlah 116 orang. Adapun teknik pengambilan sampel dengan menggunakan purposive sampling. ${ }^{11}$ Pengambilan sampel berdasarkan kriteria inklusi yaitu lansia yang berada di wilayah kerja puskesmas petaling. Kriteria eksklusi dalam penelitian ini adalah lansia yang mengundurkan diri ikut serta dalam penelitian ini.

Jumlah sampel tersebut diambil sesuai dengan kaidah jumlah sampel pada pedoman PLS (Partial Least Squares) dengan rumusan, dimana besaran sampel (Sample size) yang diambil adalah 5 hingga 10 kelipatan dari jumlah indikator yang akan diteliti. ${ }^{12}$ Sehingga dalam hal ini besaran sampel yang diambil adalah berkisar 30 hingga 60 yaitu sebesar 60 responden.

Metode analisis data yang digunakan dalam penelitian ini adalah analisis univariat, analisis bivariate dan analisis SEM (Structural Equation Modelling). Diagram jalur SEM berfungsi untuk menunjukkan pola hubungan antar variabel yang akan diteliti. Dalam SEM pola hubungan 
antar variabel akan diisi dengan variabel yang diobservasi, variabel laten dan indikator.

Data penelitian ini akan disajikan dalam bentuk (1) penyajian komposisi dan frekuensi dari sampel. Data yang disajikan pada awal hasil analisa adalah berupa gambaran atau deskripsi mengenai sampel, dimana penjelsan juga disetai ringkasan berupa tabel dari deskripsi yang utama. Hal ini dilakukan untuk membantu pembaca lebih mengenal karakteristik dari responden dimana data penelitian tersebut diperoleh. (2) Penyajian analisa SEM. Data penyajian analisa SEM dari pengolahan data output yang menggunakan bantuan SPSS 18.0 dan SmatPLS 2.0, disajikan dalam diagram, tabel dan gambar.

Cara mengetahui reliabilitas instrumen dilakukan dengan uji Cronbach's Alpha. Nilai dari hasil uji Cronbach's Alpha selanjutnya dibandingkan dengan nilai koefisien reliabilitas yang dapat diterima yaitu di atas 0,70 . Outer model yang menspesifikasikan hubungan antar variabel laten dengan indikatornya diukur dengan melihat convergent validity dengan nilai loading 0,5-0,6 dianggap cukup. Nilai pada perhitungan bootstraping dengan melihat nilai original sample yang merupakan nilai path dan nilai significancy-nya yaitu nilai $\mathrm{T}$ statistik. Nilai path tersebut signifikan bila nilai $\mathrm{T}$ lebih besar dari 1,96 yaitu tingkast kesalahan $5 \%$. Langkah selanjutnya adalah membangun persamaan untuk model dan menghitung nilai Q2 atau goodness of fit dari model yang dibangun, yaitu melalui besaran variasi data penelitian terhadap fenomena yang dikaji dengan menghitung R2 pada masing-masing variabel terlebih dahulu. ${ }^{13}$

Hasil

Penyajian hasil penelitian disusun berdasarkan sistematika yang dimulai dengan gambaran analisis univariat yang bertujuan untuk melihat distribusi frekuensi variabel dependen dan independen. Sedangkan analisa bivariat untuk melihat pengaruh antara variabel eksogen dengan variabel endogen. Kemudian diakhir penelitian ini diberikan gambaran análisis SEM untuk menjelaskan hubungan yang komplek dari beberapa variabel yang diuji dalam penelitian ini.

Jumlah sampel dalam penelitian ini adalah sebanyak 60 responden yaitu lansia Di Wilayah Puskesmas Petaling. Data penelitian dikumpulkan selama tujuh bulan yaitu pada Agustus 2016 Februari 2017.

Hasil penelitian tentang karakteristik responden sebagian besar berumur 60-74 tahun sebanyak 38 responden sebesar $63,4 \%$. Selain itu pendidikan terbanyak adalah tingkat SDSMP dengan jumlah 48 responden sebesar $80 \%$, jenis kelamin responden terbanyak adalah perempuan berjumlah 34 responden sebesar $65,7 \%$, sedangkan jenis pekerjaan yang terbanyak adalah lansia yang bekerja 43 responden atau $71,7 \%$.

Dari gambar 1 terlihat bahwa nilai faktor loading telah memenuhi persyaratan yaitu nilai loading factors di atas 0,5. Suatu indikator reflektifdinyatakan valid jika mempunyai 


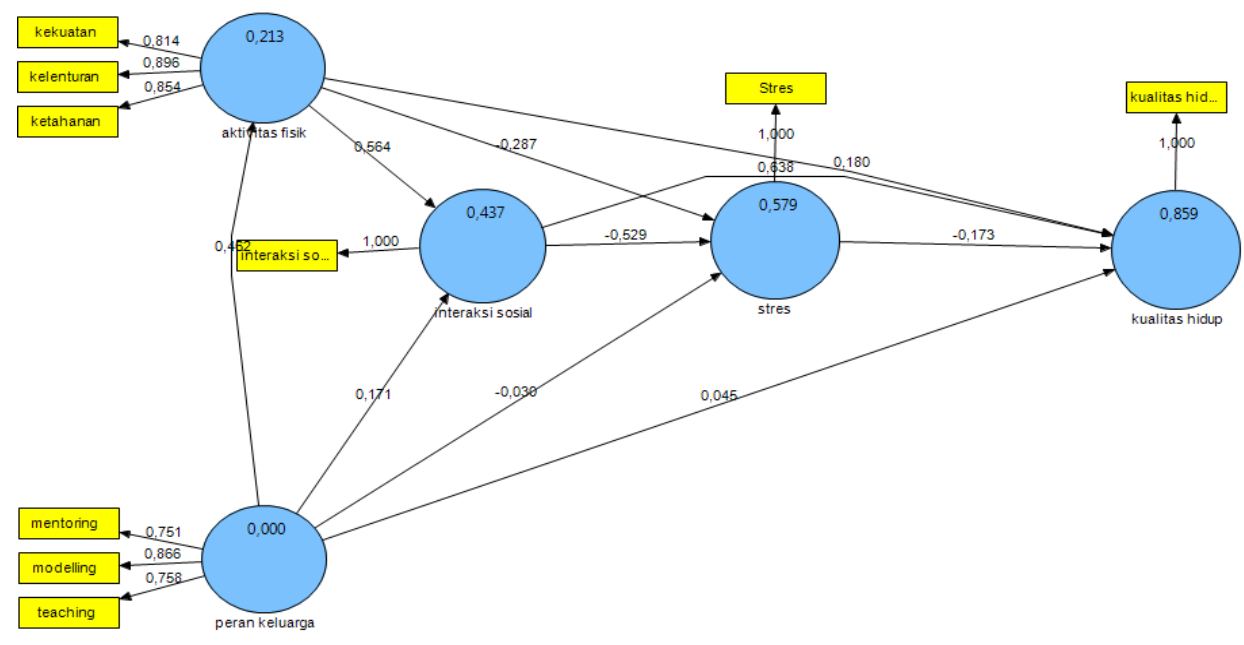

Gambar 1. Output PLS (Loading Factors)

konstruk yang dituju berdasarkan pada substantive content-nya dengan melihat signifikansi dari weight $(\mathrm{t}=1,96)$.

Hasil analisis pengolahan data terlihat bahwa konstruk yang digunakan untuk membentuk sebuah model penelitian, pada proses analisis faktor konfirmatori telah memenuhi kriteria nilai di atas batas signifikansi yaitu 0,05 . Dari hasil pengolahan data di atas, juga terlihat bahwa setiap indikator atau dimensi pembentuk variabel laten menunjukkan hasil yang baik, yaitu dengan nilai loading factor yang tinggi di mana masing-masing indikator lebih besar dari 0,5. Dengan hasil ini, maka dapat dikatakan bahwa indikator pembentuk variabel laten konstruk peran keluarga, aktivitas fisik, interaksi sosial dan stres terhadap kualitas hidup lansia tersebut sudah menunjukkan hasil yang baik.
Setelah dilakukan uji validitas dan telah dinyatakan valid variabel dan indikatornya untuk selanjutnya dilakukan uji reliabilitas. uji reliabilitas ini dilakukan dengan melihat nilai composite reliability dari blok indicator yang mengukur konstruk hasil composite reliability yang akan menunjukkan nilai yang memuaskan jika 0,70 , hasil uji menunjukkan bahwa semua variabel dinyatakan reliable karena nilai Cronbach's Alpha dan Composite reliability0,70 sehingga dapat dikatakan bahwa kontruk memiliki reliabilitas yang baik.

Gambar 2 menyatakan nilai $\mathrm{T}$ Statistik direfleksikan terhadap variabelnya sebagian besar >1,96, sehingga menunjukan blok indikator berpengaruh positif dan signifikan untuk merefleksikan variabelnya. 


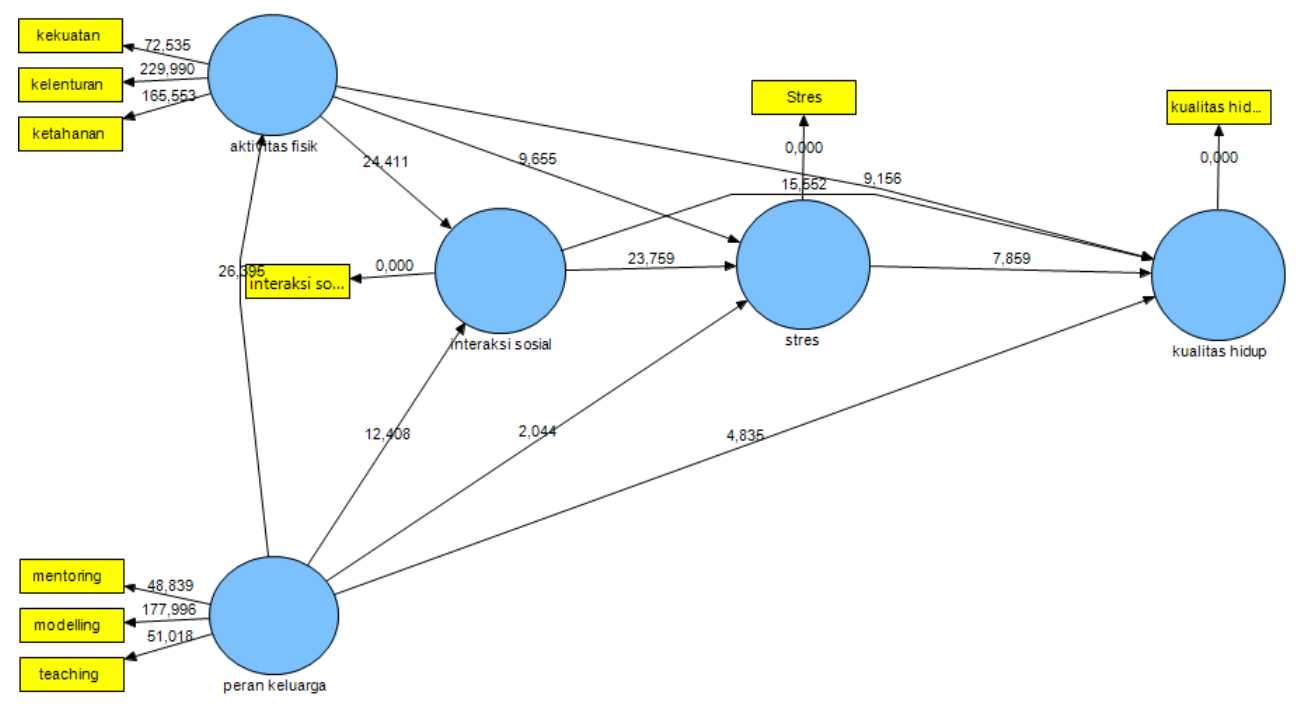

Gambar 2. Model (T-Statistic) Bootstrapping

Nilai $R$-Square

Nilai R-square pada variebel aktivitas fisik sebesar $21.3 \%$ dan sisanya $78.7 \%$ dipengaruhi faktor lain. Nilai $\mathrm{r}$ square pada interaksi sosial sebesar 43.7\% dan sisanya $56.3 \%$ dipengaruhi faktor lain. Nilai $\mathrm{r}$ square pada variebel stres sebesar $57.9 \%$ dan sisanya $42.1 \%$ dipengaruhi faktor lain. Nilai r square pada variebel kualitas hidup sebesar $85.9 \%$ dan sisanya $14.1 \%$ dipengaruhi faktor lain.

\section{Nilai $T$ Statistik}

Berdasarkan gambar 2 di atas di atas memperlihatkan bahwa semua variabel memiliki nilai t-statistik lebih besar dari $1,96 \%$ yaitu variabel peran keluarga terhadap kualitas hidup 4,836, peran keluarga terhadap aktivitas fisik 26,395, peran keluarga terhadap interaksi sosial12,408, peran keluarga terhadap stres 2,044, aktivitas fisik terhadap kualitas hidup 9,156, aktivitas fisik terhadap interaksi sosial 24,412, aktivitas fisik terhadap stres 9,656, interaksi sosial terhadap kualitas hidup 15,552 , interaksi sosial terhadap stres 23,759 , stres terhadap kualitas hidup7,859. Sehingga H0 ditolak karena nilai t-statistic tersebut berada jauh diatas nilai kritis $(1,96)$ sehingga signifikan pada $\alpha 5 \%$.

Berdasarkan gambar 1 tersebutmenyatakan bahwa interaksi sosial mempunyai nilai tertinggi terhadap kualitas hidup dengan nilai original sampel (Rho) sebesal 0,638. Sedangkan nilai pengaruh yang paling rendah adalah nilai interaksi sosial terhadap stres dengan nilai sebesar 0,527 . Nilai terbesar kedua adalah nilai dari aktivitas fisik terhadap interaksi sosial dengan nilai sebesar 0,564 . 
Tabel 2. Persentase Pengaruh Antar Variabel Terhadap Kualitas Hidup Lansia

\begin{tabular}{|c|c|c|c|c|c|c|c|}
\hline Sumber & $\begin{array}{c}L V \\
\text { Correlation } \\
\end{array}$ & Direct Path & Indirect Path & Total & $\begin{array}{c}\text { Direct } \\
\% \\
\end{array}$ & $\begin{array}{c}\text { Indirect } \\
\%\end{array}$ & \%Total \\
\hline Peran Keluarga & 0,472 & 0,045 & 0,4262 & 0,4716 & 2,14 & 0,30 & 2,44 \\
\hline Aktivitas Fisik & 0,723 & 0,180 & 0,4616 & 0,6417 & 13,01 & 0,85 & 13,86 \\
\hline Interaksi Sosial & 0,889 & 0,638 & 0,0916 & 0,7299 & 57,41 & 5,12 & 62,53 \\
\hline Stres & $-0,770$ & $-0,173$ & - & $-0,1733$ & 13,34 & & 13,34 \\
\hline Total & & & & & 85,90 & 6,27 & 92,17 \\
\hline
\end{tabular}

Sumber: Diolah dari SmartPLS 2.0 report, 2017

$\begin{array}{ccr}\text { Dari tabel } 2 & \text { menyatakan } \\ \text { menyatakan } & \text { besarnya } & \text { pengaruh }\end{array}$ langsung dan tidak langsung variablevariabel terhadap gaya hidup hipertensi. Hasil uji koefisien parameter antara peran keluarga terhadap kualitas hidup menunjukkan terdapat pengaruh langsung sebesar $2,14 \%$, aktivitas fisik terhadap kualitas hidup menunjukkan terdapat pengaruh langsung sebesar $13,01 \%$, interaksi sosial terhadap kualitas hidup menujukan terdapat pengaruh langsung sebesar $57,41 \%$ dan stres terhadap kualitas hidup menujukan terdapat pengaruh langsung sebesar $13,34 \%$. Sedangkan untuk pengaruh tidak langsung antara peran keluarga terhadap kualitas hidup menunjukkan terdapat pengaruh tidak langsung sebesar $0,30 \%$, aktivitas fisik terhadap kualitas hidup menunjukkan terdapat pengaruh tidak langsung sebesar $0,85 \%$, interaksi sosial terhadap kualitas hidup menujukan terdapat pengaruh langsung sebesar $5,122 \%$.

\section{Persamaan Matematis}

\section{Persamaan Struktural Inner Model} Secara matematis bentuk persamaan structural dari model penelitian ini adalah sebagai berikut :

$$
\eta 1=\gamma 1 \xi 1+\varsigma 1
$$

Aktivitas Fisik $=46,2$ Peran Keluarga + 53,8 Faktor Lain.

$$
\eta 2=\gamma 2 \xi 1+\beta 1 \eta 1+\varsigma^{2}
$$

Interaksi Sosial $=17,1$ Peran Keluarga + 56,4 Aktivitas Fisik + 26,5 Faktor Lain

$$
\eta 3=\gamma 3 \xi 1+\beta 2 \eta 1+\beta 4 \eta 2+\varsigma 3
$$

Stres $=-3,0$ Peran Keluarga $+-28,7$ Aktivitas Fisik + -52,9 Interaksi Sosial + 184,6 Faktor Lain $\eta 4=\gamma 4 \xi 1+\beta 3 \eta 1+\beta 6 \eta 2+\beta 5 \eta 3+\varsigma 4$ Kualitas Hidup $=4,5$ Peran Keluarga + 18,0 Aktivitas Fisik + 63,8 Interaksi Sosial +-17,3 Stres + 31 Faktor Lain.

\section{Predictive Relevance (Nilai Q-Square)}

Nilai $Q$-Square berfungsi untuk menilai besaran keragaman atau variasi data penelitian terhadap fenomena yang sedang dikaji dan hasilnya sebagai berikut:

sedang dikaji dan hasilnya sebagai berikut:

$$
\begin{aligned}
\mathrm{Q}^{2}= & 1-\left(1-\mathrm{R}_{1}{ }^{2}\right)\left(1-\mathrm{R}_{2}{ }^{2}\right)\left(1-\mathrm{R}_{3}{ }^{2}\right)\left(1-\mathrm{R}_{4}{ }^{2}\right) \\
= & 1-(1-0,213452)(1-0,436655) \\
& (1-0,579207)(1-0,858960) \\
= & 1-0.0143 \\
= & 0.9737 \text { atau } 97,37 \%
\end{aligned}
$$

Galat Model $=100 \%-97,37=2,63 \%$

Hal tersebut menunjukkan model hasil analisis dapat menjelaskan $97,37 \%$ keragaman data dan mampu mengkaji fenomena yang dipakai dalam penelitian, sedangkan 2,63\% dijelaskan komponen lain yang tidak ada dalampenelitian ini. 


\section{Pembahasan}

Pengaruh Langsung Peran Keluarga Terhadap Kualitas Hidup di Puskesmas Petaling Mendobarat Bangka Belitung Tahun 2017.

Hasil uji terhadap koefisien parameter antara peran keluarga terhadap kualitas hidup lansia di Puskesmas Petaling Mendobarat Bangka Belitung menunjukkan terdapat pengaruh langsung sebesar 2,14\% dan pengaruh tidak langsung sebesar $0,30 \%$. Nilai T-Statistic sebesar 4,835500 dan signifikan pada $\alpha=5 \%$. Nilai T-Statistic tersebut berada diatas nilai kritis $(1,96)$.

Peranan keluarga dalam memelihara dan meningkatkan kesehatan setiap anggota keluarga serta dalam menjamin keberhasilan pelayanan keluarga amat penting sekali, karena keluarga memang punya arti dan kedudukan tersendiri dalam masalah kesehatan. Peran keluarga yang sehat akan menyebabkan kualitas hidup anggota keluarganya menjadi baik. Bila peran keluarga tidak sehat maka akan dapat meningkatkan angka kesakitan dan angka kematian yang akhirnya akan menurunkan kualitas hidup. ${ }^{14}$

Apabila keluarga bahagia akan berpengaruh pada perkembangan emosi para anggotanya. Kebahagiaan diperoleh apabila keluarga dapat memerankan fungsinya secara baik.Secara sosiologis keluarga dituntut berperan dan berfungsi dengan baik untuk mencapai masyarakat sejahtera yang dihuni oleh individu (anggota keluarga) yang bahagia dan sejahtera. Fungsi keluarga perlu diamati sebagai tugas atau kewajiban yang harus diperankan oleh keluarga sebagai lembaga sosial terkecil di masyarakat. Hasil penelitian ini didukung oleh penelitian lain yang menunjukkan bahwa lansia yang tinggal bersama keluarga memiliki kualitas hidup yang lebih baik daripada lanjut usia yang tinggal di panti werdha. ${ }^{15}$
Keluarga harus dapat mengenal masalah kesehatan lansia dan mampu mengambil keputusan yang tepat untuk mengatasi kesehatan lansia. Selanjutnya keluarga juga harus merawat anggota keluarga lansia dan memodifikasi lingkungan fisik dan psikologis sehingga lansia dapat beradaptasi terhadap proses penuaan. Keluarga juga harus mampu menggunakan fasilitas pelayanan kesehatan dan sosial dengan tepat sesuai dengan kebutuhan lansia. ${ }^{16}$

Pengaruh Tidak Langsung Peran Keluarga Terhadap Kualitas Hidup di Puskesmas Petaling Mendobarat Bangka Belitung Tahun 2017.

Hasil uji terhadap koefisien parameter untuk pengaruh tidak langsung peran keluarga terhadap kualitas hidup lansia di Puskesmas Petaling Mendobarat Bangka Belitung melalui aktivitas fisik, interaksi sosial dan stres di Puskesmas Petaling Bangka Belitung sebesar 0,30\%.

Berdasarkan hasil uji tersebut dapat dijelaskan bahwa pengaruh tidak langsung peran keluarga terhadap kualitas hidup dipengaruhi oleh variabel aktivitas fisik sebesar 0,099\%, variabel interaksi sosial sebesar $0,151 \%$ dan variabel stres sebesar $0,006 \%$.

Status fungsional aktifitas seharihari terkait erat bukan hanya dengan usia, tetapi juga dengan penyakit. Keterbatasan gerak merupakan penyebab utama gangguan aktifitas hidup keseharian (Activity of Daily Living-ADL) sehingga keluarga harus berperan baik terhadap perawatan kepada lansia. Selain itu ketika lansia merasakan kebahagian dalam hidupnya itu menandakan bahwa lansia merasa bahwa hidup lansia tersebut berkualitas. ${ }^{17}$

Peran keluarga mencerminkan sikap kepedulian kepada anggota keluarganya terutama pada lansia. Seringkali lansia merasa bahwa mereka hanya menyusahkan anggota keluarga 
yang lain ketika merka tidak mampu/bergantung ketika melakukan aktivitasnya. Hal semacam ini akan menyebabkan lansia kehilangan peran dalam lingkungannya. Peran keluarga yang baik sangat dibutuhkan dalam pemenuhan kebutuhan aktivitas pada lansia. ${ }^{18}$

Pengaruh Langsung Aktivitas Fisik Terhadap Kualitas Hidup di Puskesmas Petaling Mendobarat Bangka Belitung Tahun 2017.

Hasil uji terhadap koefisien parameter antara aktivitas fisik terhadap kualitas hiduplansia di Puskesmas Petaling Mendobarat Bangka Belitung menunjukkan terdapat pengaruh langsung sebesar $13.01 \%$ dan pengaruh tidak langsung $0.85 \%$. Nilai T-Statistic sebesar 9.156155 dan signifikan pada $\alpha=5 \%$. Nilai T-Statistic tersebut berada diatas nilai kritis $(1,96)$.

Kualitas hidup lansia dapat mengalami penurunan, apabila terkena penyakit kronis seperti hipertensi, karena dapat membatasi aktivitas dari lansia sehingga akan menyebabkan penurunan Quality of Life ( $Q o L)$ lansia. Kemampuan melakukan aktivitas fisik merupakan salah satu indicator kesehatan karena lansia mampu melakukan aktivitas seperti berdiri, bekerja, dan berjalan. Kemampuan lansia untuk beraktivitas tidak terlepas dari keadekuatan system persyarafan dan muskuloskeletal. Beberapa ahli mendapatkan kesimpulan bahwa aktivitas dapat menyebabkan seseorang menjadi lebih tenang, lebih kuat menghadapi stress, gangguan hidup, dan memiliki indeks masa tubuh yang cenderung normal. Aktivitas fisik/latihan fisik yang baik, terukur, benar, dan teratur dapat mengurangi resiko terjadinya Penyakit Tidak Menular (PTM) dan dapat meningkatkan derajat kesehatan dan kebugaran jasmani. ${ }^{19}$
Aktivitas fisik yang dilakukan
secara teratur terbukti dapat meningkatkan kualitas hidup secara fisik dan mental seseorang. Peningkatan kualitas hidup secara fisik antara lain peningkatan metabolisme glukosa, penguatan tulang dan otot, serta mengurangi kadar kolesterol dalam darah. Peningkatan kualitas hidup secara mental yang diperoleh melalui aktivitas fisik ialah mengurangi stres, meningkatkan rasa antusias dan rasa percayadiri, serta mengurangi kecemasan dan depresi seseorang terkait dengan penyakit yang dialaminya. ${ }^{20}$

Pengaruh Tidak Langsung Aktivitas Fisik Terhadap Kualitas Hidup di Puskesmas Petaling Mendobarat Bangka Belitung Tahun 2017.

Hasil uji terhadap koefisien parameter antara aktivitas fisik terhadap kualitas hidup lansia di Puskesmas Petaling Mendobarat Bangka Belitung menunjukkan terdapat pengaruh tidak langsung aktivitas fisik terhadap kualitas hidup lansia di Puskesmas Mendobarat Bangka Belitung melalui interaksi sosial dan stres di Puskesmas Petaling Mendobarat Bangka Belitung sebesar $0.85 \%$.

Berdasarkan hasil uji tersebut dapat dijelaskan bahwa pengaruh tidak langsung aktivitas fisik terhadap kualitas hidup dipengaruhi oleh variabel interaksi sosial sebesar $0.744 \%$ dan variabel stres sebesar $0.088 \%$. Hasil persentase pengaruh tidak langsung aktivitas fisik terhadap kualitas hidup di Puskesmas Petaling Mendobarat Bangka Belitung lebih didominasi oleh faktor interaksi sosial.

Kemampuan melakukan aktivitas fisik merupakan salah satu indikator kesehatan karena lansia mampu melakukan aktivitas seperti berdiri, bekerja, dan berjalan.Kemampuan lansia untuk beraktivitas tidak terlepas dari keadekuatan sistem persyarafan dan musculoskeletal.Beberapa ahli 
mendapatkan kesimpulan bahwa aktivitas dapat menyebabkan seseorang menjadi lebih tenang, lebih kuat menghadapi stress, gangguan hidup, dan memiliki indeks masa tubuh yang cenderung normal. ${ }^{21}$

Aktivitas fisik yang dilakukan
secara teratur terbukti dapat meningkatkan kualitas hidup secara fisik dan mental seseorang. Peningkatan kualitas hidup secara fisik antara lain peningkatan metabolisme glukosa, penguatan tulang dan otot, serta mengurangi kadar kolesterol dalam darah. Peningkatan kualitas hidup secara mental yang diperoleh melalui aktivitas fisik ialah mengurangi stres, meningkatkan rasa antusias dan rasa percaya diri, serta mengurangi kecemasan dan depresi seseorang terkait dengan penyakit yang dialaminya. Banyak lansia yang interaksi sosialnya baik, tetapi ada juga yang interaksi sosialnya cukup dan kurang itu pun hanya sebagian lansia. Lansia yang berinteraksi dengan sesama misalnya lansia mengikuti senam pagi, ikut dalam perkumpulan lansia, memang masih ada lansia yang tidak bisa mengikuti senam ataupun perkumpulan lansia karena keterbatasan fisik mereka. ${ }^{22}$

\section{Pengaruh Langsung Interaksi Sosial Terhadap Kualitas Hidup di Puskesmas Petaling Mendobarat Bangka Belitung Tahun 2017.}

Hasil uji terhadap koefisien parameter antara interaksi sosial terhadap kualitas hidup menunjukkan terdapat pengaruh langsung sebesar $57.41 \%$ dan pengaruh tidak langsung sebesar 5.12\%. Nilai T-Statistic sebesar 15.551611 dan signifikan pada $\alpha=5 \%$. Nilai T-Statistic tersebut berada diatas nilai kritis $(1,96)$.

Berdasarkan hasil uji tersebut dapat dijelaskan bahwa pengaruh langsung interaksi sosial lebih besar nilainya dibandingkan dengan pengaruh tidak langsung dan signifikan ada pengaruh yang positif dari kedua variable tersebut. Nilai T-statitik menunjukkan, bahwa ada pengaruh signifikan antara interaksi sosial terhadap kualitas hidup lansia diPuskesmas Petaling Mendobarat Bangka Belitung Tahun 2017.

Interaksi sosial yang bagus memungkinkan lansia untuk mendapatkan perasaan memiliki suatu kelompok sehingga dapat berbagi cerita, berbagi minat, berbagi perhatian, dan dapat melakukan aktivitas secara bersama-sama yang kreatif dan inovatif. Lansia dapat berkumpul bersama orang seusianya sehingga mereka dapat saling menyemangati dan berbagi mengenai masalahnya. ${ }^{23}$

Terdapat hubungan yang signifikan antara interaksi sosial dengan kualitas hidup pada lansia. Pada teori penarikan diri, teori ini menyatakan bahwa dengan bertambah lanjutnya usia, apalagi ditambah dengan adanya kemiskinan, lanjut usia secara berangsur-angsur mulai melepaskan diri dari kehidupan sosialnya atau menarik diri dari kehidupan sosialnya atau menarik diri dari pergaulan sekitannya. Keadaan ini mengakibatkan interaksi sosial lansia menurun, baik secara kualitas maupun kuantitas sehingga sering lanjut usia mengalami kehilangan ganda (triple loss). ${ }^{24}$

\section{Pengaruh TidakLangsung Interaksi Sosial Terhadap Kualitas Hidup di Puskemas Petaling Mendobarat Bangka Belitung Tahun 2017.}

Hasil uji terhadap koefisien parameter antara interaksi sosial terhadap kualitas hidup lansia di Puskesmas Petaling Mendobarat Bangka Belitung menunjukkan terdapat pengaruh tidaklangsung sebesar $5.12 \%$. Berdasarkan hasil uji tersebut dapat dijelaskan bahwa pengaruh tidak langsung interaksi sosial terhadap kualitas hidup dipengaruhi oleh variabel variabel stres sebesar $5.12 \%$. Hasil persentase pengaruh tidak langsung 
interaksi sosial terhadap kualitas hidup lansia di Puskesmas Petaling Mendobarat Bangka Belitung hanya didominasi oleh faktor stres.

Stres pada lansia dipandang sebagai masalah yang cukup penting, karena adanya bukti bahwa stres pada lansia akan membawa kepada ketidakmampuan atau disability baik dalam fungsi fisik maupun sosial. Interaksi sosial memainkan peranan yang sangat penting dalam kehidupan lansia. Kondisi kesepian dan terisolasi secara sosial akan mempengaruhi hubungan sosial, baik sesama lansia maupun dengan pengasuh. Untuk memenuhi kebutuhan hidupnya, lansia senantiasa berinteraksi dengan lingkungan sekitarnya, saling beradaptasi, saling mempelajari, menilai dan saling melengkapi. ${ }^{9}$

Ada hubungan yang bermakna antara interaksi sosial dengan tingkat stres pada lanjut usia di Desa Lerep Kecamatan Ungaran Barat Kabupaten Semarang, sehingga para lansia lebih meningkatkan interaksi dengan sesama lansia maupun yang tinggal di lingkungan sekitar masyarakat dalam mengurangi terjadinya stress. Hal ini diakibatkan karena lansia tidak ada waktu untuk bergaul dengan masyarakat pada umumnya karena memiliki kesibukan. ${ }^{14}$

\section{Pengaruh LangsungVariabel Stres Kualitas Hidup di Puskesmas Petaling Mendobarat Bangka Belitung Tahun 2017.}

Hasil uji terhadap koefisien parameter antara stres terhadap kualitas hidup menunjukkan terdapat pengaruh langsung sebesar $13.34 \%$. Nilai TStatistic sebesar 7.859302 dan signifikan pada $\alpha=5 \%$. Nilai T-Statistic tersebut berada diatas nilai kritis $(1,96)$.

Sedangkan untuk pengaruh tidak langsung stres terhadap kualitas hidup di Puskesmas Petaling Mendobarat Bangka Belitung tidak ada nilai yang mempengaruhinya. Stres berpengaruh positif terhadap kualitas hidup lansia di Puskesmas Petaling Mendobarat Bangka Belitung.

Secara keseluruhan tampak bahwa dukungan sosial yang positif berkualitas tinggi dapat meningkatkan ketahanan terhadap stress. Hubungan stress dengan kualitas hidup bahwa stress dapat mengurangi kesejahteraan psikologis jangka pendek dan menimbulkan gejalagejala fisik. Stress dapat memperburuk kesehatan fisik dan psikoligis sehingga dapat menurunkan kualitas hidup. Dukungan sosisal sangat diperlukan pada indvidu yang mengalami stress sebagi sumber untuk melindungi individu dari stress yang berat dan memungkinkan individu untuk mengatasinya dengan baik. ${ }^{21}$

Stres dapat mengurangi kesejahteraan psikologis jangka pendek dan menghasilkan gejala-gejala fisik, sehingga stres dikatakan dapat memperburuk kesehatan fisik dan psikologis yang kemudian akan menurunkan kualitas hidup. ${ }^{23}$

\section{Kesimpulan}

Pada Penelitian ini dapat disimpulkan bahwa terdapat pengaruh langsung peran keluarga, aktivitas fisik, interaksi sosial dan stres terhadap kualitas hidup lansia. Saran-saran dalam penelitian ini adalah sebagai berikut:(1) puskesmas sebaiknya meningkatkan program posyandu lansia dan lebih mengoptimalkan senam lansia yang sudah ada sehingga para lansia mampu lebih berinteraksi kepada sesama lansia, petugas kesehatan dan kader. (2) Penelitian selanjutnya dapat memperluas objek penelitian dengan mengambil seluruh lansia yang ada diwilayah kerja Puskesmas Petaling Mendobarat Bangka Belitung, sehingga data jumlah lansia di Puskesmas Petaling Mendobarat Bangka Belitung tidak terbatas pada lansia yang mengikuti posyandu atau yang bersedia dijadikan sampel.(3) Metode penelitian ini juga hendaknya ditindaklanjuti 
dengan menggunakan metode kualitatif explanatory, melalui observasi lansung ketika mengambil data, sehingga dapat meminimalkan bias penilaian baik oleh rater maupun responden, serta dapat menambah variabel-variabel lainnya secara teori dapat mempengaruhi kualitas hidup lansia di PuskesmasPetaling Mendobarat Bangka Belitung.

\section{DAFTAR PUSTAKA}

1. Nugroho, Wahjudi. Keperawatan Gerontik \& Geriatrik Ediisi 3. Jakarta : EGC; 2008.

2. Notoatmodjo, Soekidjo. Promosi Kesehatan dan Ilmu Perilaku.Jakarta: Rineka Cipta; 2007.

3. Kompas. Jumlah Lansia Melonjak. Kompas; 2012.

4. Salamah. Kondisi Psikis Dan Alternatif Penanganan Masalah Kesejahteraan Sosial Lansi Di Panti Wredha; 2005.

5. Power, M.J. Bullinger,M., HARPER,A., \& WHOQOL Group. The world Helath Organization WHOQOL-100: Tests of the universality of quality of life in 15 ifferent cultural groups world wide. Health Psychology; 2003.

6. Kemenkes RI. Gambaran Kesehatan Lanjut Usia di Indonesia. Jakarta: Kemenkes RI; 2013.

7. Martono. Buku Ajar Geriatri (Ilmu kesehatan Usia Lanjut). Jakarta: Balai Penerbit FK UI; 2004.

8. Boen, H.,Delgard, H.B.O.S., Bjertness, E. The Importance of Social Support in The Assosiationns Between Psychological Distress and Somatic Health Problems and Socio-Economic Factors Among Older Adults Living at Home : a Cross Sectional Study.Journal BMC Geriatrics; 2012.

9. Hurlock. Psikologi Perkembangan Suatu Pendekatan Sepanjang Rentang Kehidupan. Jakarta: Erlangga; 2008.

10. Arita, Murwani. Asuhan Keperawatan Keluarga Konsep dan Aplikasi Kasus. Jogjakarta: Mitra Cendikia Press; 2007.
11. Sugiono. Metode Penelitian Pendidikan Pendekatan Kuantitatif, Kualitatif dan R\&D. Bandung: ALFABETA; 2013.

12. Latan H. Structural equation modeling konsep dan aplikasi menggunakan program SmartPLS 2.0. Bandung: Alfabeta; 2012.

13. Ghozali, I. Structural Equatin Modeling: Metode Alternatif dengan Partial Least Square, Semarang: Penerbit Universitas Diponegoro; 2008.

14. Yanta Mahareza. PerbedaanKualitas Hidup Lanjut Usia yangTinggal di Panti Werdha dan yangTinggal Bersama Keluarga. UniversitasAirlangga; 2008.

15. Tamher, S. \& Noorkasiani. Kesehatan Usia Lanjut dengan Pendekatan Asuhan Keperawatan. Jakarta: Salemba Medika; 2009

16. Fatmah. Gizi Usia Lanjut. Erlangga : Jakarta; 2010.

17. Friedman. Keperawatan Keluarga. Jakarta : EGC; 2013.

18. Kushartanti. Pengaruh latihan range of motion (ROM) terhadap fleksibilitas sendi pada lansia di Panti Wreda Wening Wardoyo Ungaran ; 2006.

19. Acree L, Longfors J. Physical activity is related to quality of life in elder adults; 2006.

20. Soerjono, Soekanto. Sosiologi Suatu Pengantar. Jakarta: PT Raja Grafindo Persada; 2013.

21. Farizati Karim. Panduan Kesehatan Olahraga Bagi Petugas Kesehatan. Depkes RI; 2004.

22. Potter, P.A. and Perry, A.G. Fundamental Keperawatan, Konsep, Proses dan Praktek. Edisi Empat, Jakarta: EGC; 2005.

23. Andreas. Interaksi Sosial Dan Kualitas Hidup Lansia Di Kelurahan Lansot Kecamatan Tomohon Selatan; 2012.

24. Loly, I S. Hubungan antara Stress dengan Konsep Diri pada Penderita Diabetes Mellitus Tipe 2; 2010. 
